Revue d'histoire de l'Amérique française

MAQ REVUE D.HISTOIRE DE L'AMÉRIQUE FRANÇAISE

\title{
Les biens de Saint-Sulpice et « The Attorney General Stuart's Opinion Respecting The Seminary of Montreal » (10 décembre 1828)
}

\section{Essai critique}

\section{Georges-Émile Giguère}

Volume 24, numéro 1, juin 1970

URI : https://id.erudit.org/iderudit/302955ar

DOI : https://doi.org/10.7202/302955ar

Aller au sommaire du numéro

Éditeur(s)

Institut d'histoire de l'Amérique française

ISSN

0035-2357 (imprimé)

1492-1383 (numérique)

Découvrir la revue

Citer cet article

Giguère, G.-É. (1970). Les biens de Saint-Sulpice et « The Attorney General Stuart's Opinion Respecting The Seminary of Montreal » (10 décembre 1828) : essai critique. Revue d'histoire de l'Amérique française, 24(1), 45-77.

https://doi.org/10.7202/302955ar d'utilisation que vous pouvez consulter en ligne. 
Essai critique

\title{
LES BIENS DE SAINT-SULPICE \\ ET 'THE ATTORNEY GENERAL STUART'S OPINION RESPECTING THE SEMINARY OF MONTREAL"
}

\author{
(10 décembre 1828)
}

Il faudra bien tenter un jour d'expliquer certains faits qui ont suivi la conquête du Canada par l'Ángleterre. Pourquoi, par exemple, les communautés d'hommes ne reçurent-elles pas de la part de l'autorité anglaise le même traitement que les communautés de femmes ? Peut-être question d'influence ou de rayonnement exercé par chacune d'elles sur la population civile ? Question en somme de formes de ministère pratiquées dans l'enseignement, les œuvres hospitalières ou l'apostolat paroissial ou missionnaire. Il y a certainement autre chose qu'une simple relation d'Eglise à Etat. Et pourquoi, parmi les communautés masculines, certaines furent-elles inquiétées, harcelées à propos de leurs biens ? Devrait-on y voir, entre autres choses, un embarras au plein exercice de la liberté religieuse ?

Quoi qu'il en soit, nous ne voulons pas pour le moment chercher une réponse à ces différentes questions. Nous voulons plutôt concentrer notre attention sur un document qui, parmi de nombreux autres, fait surgir de telles questions. Cette pièce, qui concernait les Biens de Saint-Sulpice, est une sorte d'opinion légale émanée d'un procureur général.

Situons d'abord un peu le problème, en rappelant que le Séminaire de Montréal était depuis plus d'un siècle et demi seigneur de l'Ile de Montréal. On sait déjà que la propriété de cette seigneurie et de quelques autres rattachées à Saint-Sulpice avaient été fréquemment contestées depuis 1760 et devaient continuer à l'être jusqu'à leur reconnaissance finale par le Conseil spécial de 1839. Or en 1826, un groupe de marchands et d'industriels anglais de Montréal a protesté contre les inconvénients du régime seigneurial dans une ville qui prenait place au sein de la seigneurie de l'île de Montréal, détenue par les Sulpiciens. Jusque-là le gouvernement de Londres sentant l'embarras d'une telle situation avait préféré la temporisation. 
La protestation des marchands de Montréal donna au problème seigneurial des Sulpiciens une nouvelle acuité et le gouverneur Dalhousie en profita pour demander une "opinion légale" à son ami James Stuart qu'il avait lui-même nommé procureur général. Le 10 décembre 1828, le juriste signa son document en réponse aux quatre questions que lui avait fait poser le gouverneur six mois plus tôt.

$\mathrm{Au}$ moment de rédiger sa pièce, James Stuart paraissait jouir d'un certain prestige. Procureur général et conseiller exécutif, il avait jusque-là partagé sa vie entre la pratique du droit, l'exercice de hautes fonctions publiques et une activité politique remarquée. Ses amis, au nombre desquels on comptait le gouverneur Dalhousie, avaient pour lui une grande admiration. Mais il faut également savoir que l'opinion publique ne partageait pas les mêmes sentiments et nous verrons pourquoi.

Le texte qu'il a alors produit peut avoir une certaine importance en histoire canadienne et mérite pour cette raison qu'on en fasse l'examen critique. Lecture faite, nous pourrons mieux scruter le contenu avant d'en venir finalement à la carrière de son auteur.

$$
\text { I. - Le texte }
$$

THE ATTORNEY GENERAL STUART'S OPINION RESPECTING THE SEMINARY OF MONTREAL.

To His Excellency Sir James Kempt, Knight Grand Cross of the Most Honorable Military Order of the Bath, Lieutenant General and Commander in Chief of all His Majesty's Forces in the Provinces of Lower Canada and Upper Canada, Nova Scotia and New Brunswick, and their several dependencies, and in the Island of Newfoundland, and Administrator of the Government of the Province of Lower Canada, \&c., \&c.

\section{MAY IT PLEASE YoUR EXCELLENCY:}

I have been honored with the commands of His Excellency the late Governor in Chief, signified in Mr. Secretary Cochran's letter of the 17th June last, transmitting an extract from a report of His Majesty's Executive Council, of the 6th May preceding, on a reference respecting the Seminary of Montreal, and requiring my opinion on certain points specified in that Report, and also such information and suggestions on the subject as I might have it in my power to offer.

1 - In obedience to these commands I have considered the matter referred to me, and with all deference have now the honor of submitting to His Excellency the Administrator of the Government the opinion and information which have been required.

2 - Before proceeding to state this opinion, it would seem fit to mention succinctly the facts on which it is grounded, and which are of public notoriety, or cannot be questioned. 
3 - On the 9th March, 1663, an association of individuals which had been established for the conversion of the Indians, on the Island of Montreal, and known under the name of, "Les associés pour la conversion des Sauvages "de la Nouvelle France, en l'Isle de Montréal," executed a deed of gift to the Seminary of St. Sulpice of Paris, of the whole Island of Montreal, which was then and had been for some years previously held by that association, as a Seignory $\grave{a}$ titre de fief. In this instrument, the motive of the gift, and the purpose of its application are expressly stated to be the conversion of the Indians of New France, and it is declared that "le "domaine et propriété de la dite Isle sera inséparablement uni au dit Sémi"naire sans en pouvoir être séparé, pour quelque cause et occasion que "ce soit." Fourteen years after the execution of this deed of gift, His Most Christian Majesty, by letters patent bearing date in May, 1677, authorised the establishment of a Seminary at Montreal, for effectuating the object for which the Island had been thus given to the Seminary of St. Sulpice.

4 - In these letters patent, after reciting the deed of gift above mentioned, and stating that the Seminary of St. Sulpice at Paris had successfully employed Missionaries whom they had sent out, in the conversion of the Indians, on the Island of Montreal, and were desirous of establishing a community there, in furtherance of that object, if His Majesty should be pleased to grant his permission to that effect, it was declared that on these considerations His Majesty authorised the Seminary of St. Sulpice at Paris to erect a Community and Seminary of Ecclesiastics on the Island of Montreal, for accomplishment of the purpose in view; and expressing his approbation of the deed of gift. His Majesty granted his license to the Seminary of St. Sulpice at Paris to hold in mortmain the Seigniory of Montreal, which had been granted to them by that deed, declaring it to be his will and pleasure "qu'elle soit unie, à perpétuité, à leur société, etc., "pour en jouir par eux et leurs successeurs, etc."

5 - Under the deed of gift above mentioned, and the letters patent in part recited, the Seminary of St. Sulpice at Paris, having become possessed of the Island of Montreal, established a Community of Ecclesiastics there, which has been since known by the name of the Seminary of Montreal.

6 - This community under the letters patent of May, 1677, was necessarily composed entirely and exclusively of members of the Community of St. Sulpice of Paris, which latter community continued, in its own name, to exercise acts of ownership in relation to the Island of Montreal, down to the period of the conquest by the British arms, in 1760: and in all public instruments anterior to that period, in which the ownership of the Island was in question, or made mention of, the Seminary at Paris was invariably designated and referred to as the owner of it.

7 - By the capitulations which preceded the conquest of Canada, no stipulation was made, under which the members of the Seminary of St. Sulpice at Paris, or of the Seminary of Montreal, could claim a right to subsist as a corporation. On the contrary, although a demand to that effect was made it was expressly negatived. The 32nd Article of the capitulation which preceded the surrender of Montreal permitted the Communities of Nuns to subsist, in the following words, viz; "The Communities of Nuns "shall be preserved in their constitutions and privileges; they shall continue "to observe their rules, \&c. Granted." But by the 33rd Article of the same capitulation a similar right was refused to the Seminary of Montreal, in the following words, viz: "The preceding Article shall likewise be executed 
"with regard to the Communities of Jesuits and Recollets, and the House "of the Priests of St. Sulpice at Montreal; these last and the Jesuits shall "preserve their right to nominate to certain curacies and missions, as "heretofore. Refused, till the King's pleasure be known."

$8-$ By the 4th Article of the Treaty of Peace concluded between His Britannic Majesty and His Most Christian Majesty, on the 10th February, 1763, the latter ceded and guaranteed Canada and all its dependencies to His Majesty, in full right, with the Sovereignty, property, possession thereof, \&c., and it was agreed on the part of His Majesty to grant the liberty of the Catholic Religion to the inhabitants of Canada, with permission to such of them as chose to retire, to sell their estates, and emigrate thence within eighteen months.

9 - Four years after the conquest a conveyance bearing date the 29th April, 1764, was executed by certain members of the Seminary of St. Sulpice at Paris to a Mr. Montgolfier, in character of Superior of the Seminary of Montreal, the object of which was to convey and assure to that Seminary the estates possessed by the former in Canada, of which the Island of Montreal made part. To this instrument a specific name can hardly be given, but it would seem to possess the character of a deed of gift rather that that of any other description of conveyance. In it a recital is given of the several titles under which the Seminary of St. Sulpice at Paris had acquired its estates in Canada, and the members of that Seminary, who are parties to the instrument in consideration, (as they state,) of the difficulties and embarrassments in which they found themselves involved by the conquest, grant and make over all their estates in Canada to the Seminary of Montreal.

10 - Subsequent to the conquest a certain number of the members of the Seminary of St. Sulpice of Paris who were in Canada at the time that event occurred, continued to reside there, retaining possession of the estates which had belonged to that community, and it is supposed that the survivor of these individuals died at Montreal about the year 1795 or 1796. As well before as since his death, the estates have been and continue to be in possession of persons who ascribe to themselves a corporate character, as composing the Seminary of Montreal, and who have received and applied the revenues derived from them to such purposes as they have thought fit, without having been subjected to any visitation, control, or accountability whatever, in the disposal of them.

11 - The Gentlemen composing this body, since the period last mentioned, with few exceptions, have been natives of France, not naturalized; and the Rev. Mr. Roux, in particular, who since that period has been and still is Superior of the Seminary, is a native of that country, and has not been naturalized, though he has received within the colony Letters of Denization.

12 - The purpose for which the original donors granted the Island of Montreal to the Seminary of St. Sulpice of Paris, namely, "the conversion of the Indians," has, since the establishment of the Seminary at Montreal, it is also proper to state, been entirely overlooked and neglected. It does not appear that the revenues derived from the Island, which it is known have been very considerable, have ever been applied to the fulfilment of the object for which that estate was given; and this condition, on which the grant was made, and the Seminary of Montreal received its legal existence, continues to be unaccomplished. The Seminary of Montreal has indeed, it would appear, altered the purpose of its institution, which was 
of a special and specific nature, by applying its funds to an object which would properly belong to a Diocesan Seminary, under the guidance and control of a Bishop, namely, to the education of persons intended for the Priesthood, with which it has conjoined the education of the French Canadian youth generally. For this purpose it has maintained an institution called a College on a considerable scale. To what other objects the revenues of its estates may have been applied is not known, though it is understood that large sums were some years since expended by the Seminary in the establishment of another Seminary and College at Baltimore, in the United States of America.

13 - On these facts the following questions would seem to embrace the several points on which I am desired to give an opinion, and also the information which is required:

10. What was the effect of the conquest of Canada with respect to the estates held there by the Seminary of St. Sulpice of Paris ?

2o. Was the conveyance from the Seminary of St. Sulpice of Paris to the Seminary of Montreal, on the 29th April, 1764, legal, and can the latter Seminary derive any right to the estates in question under that conveyance?

3o. Had the Seminary of Montreal ever any legal existence as a corporation distinct from the Seminary of St. Sulpice of Paris, and is it now a subsisting corporation?

4o. What is the legal course to be taken for the purpose of enforcing the rights which have accrued to His Majesty in the estates held by the Seminary of Montreal, and also to obtain a judicial determination on the claim of the Seminary of Montreal, to a corporate character ?

14 - Upon the first question,-I conceive no doubt can be entertained that the Island of Montreal, being the property of the Seminary of St. Sulpice of Paris, a religious community, established and subsisting there at the time of the conquest, or to speak more accurately, being public property in the hands of that community as trustees for its administration and application, was acquired by His Majesty by right of conquest, and must be understood to have been since held by the persons in possession of it by the sufferance of His Majesty, and subject to such appropriation, uses and purposes, as His Majesty may think fit to declare. There is, I apprehend, no stipulation in either of the capitulations which preceded the conquest of Canada, under which the Seminary of St. Sulpice at Paris could claim an exemption from the operation of the law of nations in this particular, under which His Majesty's right has been derived. But independently of this source of right, the legal estate in the Seigniory of the Island of Montreal being vested in a foreign religious community incapable after the conquest of holding lands in a country subject to His Majesty's dominion, the right of property in it, from this cause alone, would necessarily devolve to His Majesty.

15 - Upon the second question,-If, as assumed in the answer to the preceding question, no right could be claimed by the Seminary of St. Sulpice of Paris, under the capitulations to sell their estates in Canada, the alleged disposal of it by deed of gift would of course be null and void. But I am humbly of opinion, that on other grounds the pretended deed of gift of the 29th of April, 1764, must be considered an absolute nullity. Under any circumstances, and with the observance of any formalities, I should conceive the Seminary of St. Sulpice could not alienate the estates held by them in Canada. They were vested with no right of property in these 
estates, but held them merely as trustees or administrators for a charitable public use or purpose, and being incapable of conveying to another person a larger extent of right in the estates than they themselves held, it must, I apprehend, be considered that they could not alienate them in any form. But in the particular mode of conveyance which they adopted, it is certain they could not dispose of them legally.

16 - In the deed of gift referred to the grantors and grantees were members of one and the same corporation, they had individually no beneficial right or interest whatever in the estates which were made the subject of the conveyance. These were not the property of the individuals composing the corporation, but that of the corporation itself, res universitatis, and were therefore incapable of alienation by one part of the members of the corporation to another part, nor were they susceptible of partition among them. On this ground, the deed of gift must be held void from the disability of the contracting parties to enter into such a contract. But it was also absolutely void on the ground of the incapacity of the grantees to take the estates proposed to be conveyed to them. If (as is not admitted but denied) the Seminary of Montreal had been a subsisting corporation, distinct from the Seminary of St. Sulpice, it could not have taken the estates in question without a license in mortmain. The French as well as the English law rendered "lettres d'amortissement," or a license in mortmain indispensably necessary for the validity of the deed of gift in question. Even if, in other particulars, it could have been deemed valid, the nullity of it, from the want of such authority, cannot be doubted.

17 - Upon the third question,-Under the French law, as it has obtained in this Province, no corporation could be established otherwise than by the Royal authority, which was conveyed by letters patent. No length of possession of a corporate existence, without this authority. Nor was it competent to corporations already existing, to form new establishments, institutions or religious houses, without the express permission of the Sovereign.

18 - It was in conformity with the law on this head that the Seminary of St. Sulpice of Paris, a subsisting corporation, legally established, applied to His Most Christian Majesty to form a Seminary or religious house at Montreal, for the accomplishment of the intentions of the original donors of the Island of Montreal, in granting that island to them. In compliance with this application, His Most Christian Majesty, by letters patent of May 1667, [1677] permitted them to form a Seminary at Montreal; but this Seminary was to be composed of the members of the Seminary of St. Sulpice at Paris, and of no other persons, and was therefore only an institution of the corporation of St. Sulpice at Paris under a different name, and a mere dependance of that corporation, whose principal establishment or house was at Paris.

19 - On this ground, I am humbly of opinion that the Seminary of Montreal never had legal existence as a corporation distinct from the Seminary of St. Sulpice at Paris. But if it could be said to have had such corporate existence, I am also of opinion that, on several grounds, it has long since lost it, and that it has since a distant period been merely a private association of individuals, who have without authority assumed to themselves a corporate name. In the absence of any stipulation to the contrary by capitulation or treaty, the conquest of Canada, I apprehend, by the law of nations, extinguished all political institutions and franchises derived from the authority of the Sovereign from whom Canada was wrested 
by force of arms; and among these the Seminary of Montreal, if it had legal existence as a corporation, became extinct. But this point does not rest on the general effect of a conquest, in extinguishing political franchises, inasmuch as in this particular case, upon a demand made in the proposed capitulation of Montreal, that the Seminary should be preserved in its constitutions and privileges, this demand was expressly refused, till the King's pleasure should be known. And I am not aware that, by any legal signification of the Royal pleasure, the Seminary of Montreal has since been re-integrated in a corporate character, if such it ever had.

20 - But from the nature of the constitution of the Seminary of Montreal it was utterly impossible that, under any circumstances, without a new charter, its existence as a corporation (if such it had) could be prolonged beyond the lives of the members of the Seminary of St. Sulpice, who remained in Canada after the conquest. For, as no persons could be members of the Seminary of Montreal, who were not members of the Seminary of St. Sulpice at Paris, and as a supply of new members could not be derived from the parent establishment after the conquest, the duration of the Seminary of Montreal was necessarily limited to the lives of the members who remained in Canada; and the last of these having died about the year 1795 or 1796 , the Seminary necessarily became extinct at that time by the death of all its members.

21 - In this respect the Seminary of Montreal, and also the Recollets and Jesuits were disadvantageously distinguished from the other religious communities in the Province, inasmuch as the latter, according to the rules of their foundation, could obtain a renewal of their members by a domestic supply, whereas the former could only receive it from the alien parent establishments in Europe, to which they belonged, and this source was closed by the conquest. The latter might avail themselves of a permission from His Majesty to elect new members after the conquest, the former could not. The means which appear to have been resorted to by the Seminary, since the death of the survivor of its members who continued to reside in Canada after the conquest, to supply the requisite succession in the persons composing it, namely, the introduction of aliens, members of the Seminary of St. Sulpice at Paris, to assume places in the Seminary at Montreal, I am humbly of opinion have been illegal. The conquest having had the effect of severing the Seminary of Montreal altogether from the Seminary of St. Sulpice at Paris, no title to a corporate right in the former could be derived from the latter after that event, and persons subsequently admitted to be members of the latter Seminary could, therefore, have no claim, on that ground to be members of the former. Besides, as being aliens, they would be disqualified from being so. According to the law of France and the law of this Province as it now stands, aliens and even denizens are incapable of being members of a corporation.

22 - The French law as it was received into this Province prior to the conquest was particularly rigid on this head. Pothier, one of the best writers on that law, in his "Traité des personnes," says, "Les étran"gers ne peuvent ni posséder un bénéfice, ni tenir un office, ni faire "aucune fonction publique dans ce royaume." And he refers to an ordinance of 1431, "qui rend les étrangers, de quelque qualité qu'ils soient, inca"pables de tenir archevêchés, évêchés, abbayes, dignités, prieurés, et autres "bénefices, de quelque nature qu'ils soient en France." He also states that this disqualification extended to the chief offices in seats of learning, and that aliens could not be principals or regents of a university. Letters of naturalization, or "lettres de capacité," were indispensably necessary to 
remove this disability. Aliens not naturalized, or rendered competent by a special dispensation, which is to be understood by "lettres de capacité," could not, therefore, occupy places in any religious corporation in this Province,

23 - It is also fit to be observed that the Seminary, if it had a corporate existence, might be considered to have forfeited it, by a nonfulfilment of the condition on which it was established.

24 - It is a matter of notoriety that there has been a non-user of the franchise which was granted to the Seminary of St. Sulpice of Paris, by the letters patent of May, 1667. Neither the labours nor the revenues of the Seminary of Montreal have been or are likely to be applied to "the conversion of the Indians." There is, therefore, a large disposable eleemosynary fund in the hands of the Seminary of Montreal, which may receive such application as His Majesty's Government, in its wisdom, may deem proper.

25 - Upon the fourth question, - A real action, called in the law of this Province an action petitoire, may be brought in the name of His Majesty against the persons in possession of the Seigniory of the Island of Montreal by which I am humbly of opinion that His Majesty's rights may be effectually enforced, and the possession of that estate obtained. In order, also, that a judicial determination may be formally had on the claim of the Seminary to be a corporation, an information quo warranto might be fyled against the persons who have assumed to themselves a corporate character, under the name of the Seminary of Montreal.

26 - By these remedies, I am humbly of opinion, the rights of His Majesty may in all particulars be secured and maintained.

All which, nevertheless, is most respectfully submitted to Your Excellency's wisdom, by

Your Excellency's

Most obedient humble servant,

J. STUART,

Quebec, 10th December, 1828.

Attorney General.

Robert Christie : Interesting Public Documents and Official Correspondence - To the History of Lower Canada (Montreal, 1855), Vol 6 : 424-434.

$$
\text { II. - Critique interne du texte }
$$

Si nous omettons le titre, le protocole d'introduction et le préambule, nous observons que Stuart a divisé son texte en deux grandes parties. L'une, historique, couvre la portion que nous avons numérotée de 1 à 12 ; l'autre, juridique, va du numéro 13 au paragraphe 26.

\section{A. - PARTIE historique}

"Before proceeding to state this opinion, it would seem fit to mention succinctly the facts on which it is grounded, and which are of public notoriety, or cannot be questioned." (Par. 2.) 
Il ne serait nullement erroné de dire que cette partie historique devait tenir dans ce document la place et le rôle des "considérants" dans une pièce juridique d'importance équivalente.

Une vérification des faits rapportés, parfois trop "succinctement", nous amène précisément à remettre tout le document en question parce que cette partie "on which it is grounded" demande des rectifications même dans la partie juridique. La division entre histoire et droit est une façon de parler assurément, vu que ces points de vue n'étaient ni ne pouvaient être étanches l'un à l'autre et qu'au contraire ils s'influençaient réciproquement.

C'est alors tout un document qu'il faudrait rebâtir. Il paraîtra suffisant toutefois de redresser les erreurs qui s'y sont glissées soit par incompétence, soit par négligence. Nous excluons la malveillance jusqu'à preuve du contraire.

1. Pour le régime français

\section{a - Documents uTILISÉs}

i. - "Contrat de donation au dit Séminaire, en date du 9e Mars 1663" 1 .

ii. - "Etablissement d'un Séminaire dans l'Isle de Montréal, et amortissement pour la Seigneurie de la dite Isle" 2 .

\section{b - UTILISATION ET OMISSIONS}

"Les associés pour la conversion des Sauvages de la Nouvelle-France, en l'Isle de Montréal" (par. 3) était le nom de la société donatrice. Si Stuart avait continué sa lecture du "Contrat de donation" il aurait trouvé le but de cette société qu'il n'aurait pas confondu de façon préjudiciable avec le nom. Parcourons ce passage du Contrat :

Considérant les grandes bénédictions qu'il a plu à Dieu répandre sur la dite Isle de Montréal pour la conversion des sauvages, instruction et édification des Français habitués en icelle par les soins... dans ces derniers temps [des] messieurs du Séminaire de Saint-Sulpice [qui] ont travaillé par leurs soins et par leur zèle pour soutenir ce bon œuvre...

Et ce but, il l'aurait d'ailleurs reconnu dans le document royal de mai 1677 établissant le Séminaire de Montréal et amortissant à perpétuité la Seigneurie de l'Ile de Montréal.

${ }^{1}$ Edits et Ordonnances royaux (Québec, 1803) : 81-85; (1854) : 93-97.

2 Edits et Ordonnances royaux (Québec, 1803) : 80-81; (1854) : 91-92. 
A ces causes, bien informé que nous ne pouvons rien faire de plus avantageux pour la propagation de la foi et pour l'établissement de la religion chrétienne dans nos Etats de la Nouvelle-France... à la conversion et instruction de nos sujets...

Distraction grave et préjudiciable parce qu'elle engendrait, sous la plume de Stuart, une expression vague et laconique comme "for the accomplishment of the purpose in view" (par. 4), et l'entraînait dans une ambiguïté d'où il allait tirer ensuite ses arguments majeurs. Il aurait remarqué d'autre part que les deux documents avaient été dûment insinués au Conseil Supérieur de Québec, Registre A, folio $67 \mathrm{v}^{\circ}$, par Becquet, le 20 septembre 1677. Un juriste averti n'aurait pas négligé des précautions légales qui avaient donné force de loi à la fondation du Séminaire de Montréal, donc à son existence légale, aux titres de possession à perpétuité, donc à l'amortissement tout en précisant le but de la donation.

Sans ces négligences inexplicables chez un juriste et, à plus forte raison, chez un procureur général, dans une question de cette importance, une grande partie de son argumentation n'aurait même pas pu voir le jour. Ces mises au point faites devraient nous dispenser de rectifier une opinion légale qui $y$ perd d'un seul coup son principal sinon son unique fondement.

2. Pour le régime anglais

a - Documents UTILISÉS

i. - Capitulation du Canada à Montréal, art. 32 et 33.

ii. - Traité de Paris, art. 4.

iii. - Acte du 29 avril 1764, intitulé "Concession et abandon. Le Séminaire de Saint-Sulpice à celui de Montréal" par $\mathrm{M}^{\bullet}$ Petit, $\mathrm{N}^{\mathrm{re}}$ à Paris $^{3}$.

\section{b - UTILISATION ET OMISSIONS}

L'argument du silence de la Capitulation, tel qu'invoqué par Stuart (par. 14) a perdu tout son poids à la suite des précisions apportées plus haut, même qu'il joue en sens tout à fait contraire. Le Séminaire de Montréal existait légalement, il avait des titres légaux de possession sur des biens légalement amortis par le roi de France dans l'intention de servir au but de la donation. Aucun document de la capitulation n'avait révoqué ces droits. Bien au contraire puisque les articles 34 et 35 de la capitulation,

3 Archives de Saint-Sulpice de Paris ASSP, dossier 109, nº 21. 
que ne mentionne même pas Stuart, garantissaient à SaintSulpice de Montréal son droit de propriété. On n'y découvre aucune ambiguïté.

Art. 34. Toutes les Communautés, Et tous les prestres Conserveront Leurs Meubles, La propriété, Et L'Usufruit des Seigneuries, Et Autres biens que les Uns et les Autres possedent dans la Colonie de quelque Nature qu'ils Soient, Et Les d: biens seront Conservés dans leurs privilèges, droits, honneurs, et Exemptions. (Rép.: Accordé.)

Art. 35. Si Les Chanoines, Prestres, Missionnaires, Les Prestres du Seminaire des Missions Etrangeres Et de St Sulpice, ainsi que les Jesuites et les Recolets, Veulent passer En france, Le passage leur sera Accordé sur les Vaisseaux de Sa Majesté Britanique; Et Tous auront la Liberté de Vendre, En total ou partie, Les biensfonds, Et Mobiliers qu'ils possedent dans la Colonie, soit aux françois, ou aux Anglois, sans que le Gouvernement Britanique puisse y mettre le moindre Empeschement ni Obstacle.

Ils pouront Emporter avec Eux, ou faire passer En france Le produit de quelque Nature qu'il soit, des d biens Vendus, en payant Le fret, Comme Il est dit à L'Article 26.

Et Ceux d'Entre Ces Prestres qui Voudront passer Cette Année, Seront Nouris pendant La Traversée aux dépens de Sa Mté Britannique, Et pouront Emporter avec Eux leurs bagages.

(Rép.: Ils seront les maîtres de disposer de leurs biens, et d'en passer le produit, ainsi que leurs personnes, et tout ce qui leur appartient, En france.)

Quant à l'article 4 du traité de Paris, loin d'entamer en rien la propriété privée, il la garantissait de façon très explicite, quoique en termes généraux.

Sa Majesté Britannique convient en outre, que les Habitants François ou autres, qui auroient eté Sujets du Roy Très Chretien en Canada, pourront se retirer en toute Sûreté \& Liberté, où bon leur semblera, et pourront vendre leurs Bien, pourv* que ce soit à des Sujets de Sa Majesté Britannique, \& transporter leurs Effets, ainsi que leurs Personnes, sans être genés dans leur Emigration... Le Terme limité pour cette Emigration sera fixé à l'Espace de dix huit Mois, à compter du Jour de l'Echange des Ratifications du present Traité.

Contrairement à ce que soutenaient les juristes anglais depuis l'opinion de Marriott en 1774, et des juristes de 1789, reprise par l'avocat dans la cause Fleming, la propriété des communautés d'hommes et de femmes était, au même titre que tout autre particulier, propriété privée, compte tenu évidemment de la législation française et du droit seigneurial.

L5acte du 29 avril 1764 avait été passé par-devant notaires, après consultation, en mars 1764 , de $M$. Guerchi, ambassadeur de France en Angleterre, qui avait obtenu l'assentiment du roi britannique sur la teneur entière du document. De plus le document respectait le délai de dix-huit mois accordé par le traité 
de Paris et qui allait échoir seulement le 10 août 1764 . Il n'avait pas été rédigé, comme le dit vaguement Stuart "four years after the conquest" (par. 9), ce qui aurait donné septembre 1764, si toutefois la capitulation de Montréal avait eu cet effet sans le traité de Paris.

Examinant la nature de cette pièce, Stuart pouvait difficilement se prononcer. "To this instrument a specific name can hardly be given, but it would seem to possess the character of a deed of gift rather than that of any other description of conveyance." (Par. 9) Impression assurément puisque c'est une renonciation à la co-propriété, renonciation imposée par la conquête aux Sulpiciens de Paris, devenus étrangers au Canada. Renonciation qui laissait l'entière possession au Séminaire de Montréal. Ce n'était pas même une mutation, aux termes du droit féodal, ni une disposition, ni une aliénation, comme l'insinuait Stuart au paragraphe 15.

Quelques autres questions de droit suivent encore et qui reviendront dans la seconde partie, sous forme d'interprétation. Nous nous contenterons pour le moment de les mentionner. L'amortissement à perpétuité fait par Louis XIV en 1677 et jamais révoqué par la suite dirime l'objection tirée de la mort des derniers Sulpiciens du temps de la conquête. La naturalisation reviendra plus longuement dans la partie légale. Quant au but de la donation de 1663 , nous en avons disposé plus haut à l'aide des textes. Les largesses de Saint-Sulpice de Montréal dans l'accomplissement de ce but, soit en faveur de la religion et de l'éducation, même au XIX ${ }^{e}$ siècle, étaient connues du public. Mais entre les mains de Stuart elles ont semblé perdre toute leur valeur du seul fait qu'il ait présenté une fausse image du but de la donation. Pour ce qui concerne la participation à la fondation du Séminaire et du Collège de Baltimore, il a été impossible d'en faire vérification.

\section{Fin de la partie historique}

Stuart termine cette partie de la façon suivante : "On these facts the following questions would seem to embrace the several points on which I am desired to give an opinion." (Par. 13)

Il ne faut pas oublier que déjà plusieurs points de droit ont été engagés. Les faits établis par Stuart avec négligence, les allusions aux textes faites parfois à contresens marquaient un mauvais départ et mettaient en sérieux danger l'opinion légale. Mais attendons pour voir. 


\section{B. - La PARTiE LÉGALE}

La deuxième partie qui doit normalement constituer l'“opinion légale" du procureur général, commence par les questions soumises à son jugement.

1. Les questions posées

$1^{\circ}$ What was the effect of the conquest of Canada, with respect to the estates held there by the Seminary of St. Sulpice of Paris ?

$2^{\circ}$ Was the conveyance from the Seminary of St. Sulpice of Paris to the Seminary of Montreal, on the 29th April, 1764, legal, and can the latter Seminary derive any right to the estates in question under that conveyance?

$3^{\circ}$ Had the Seminary of Montreal ever any legal existence as a corporation distinct from the Seminary of St. Sulpice of Paris, and is it now a subsisting corporation?

$4^{\circ}$ What is the legal course to be taken for the purpose of enforcing the rights which have accrued to His Majesty in the estates held by the Seminary of Montreal, and also to obtain a judicial determination on the claim of the Seminary of Montreal, to a corporate character ? (Par. 13)

Ces questions soulevaient des problèmes profondément imbriqués les uns dans les autres. Au point que Stuart non seulement les a déjà inclus dans la partie historique mais qu'il doit y revenir à deux ou trois endroits différents.

Aux quatre questions posées au procureur général de 1828, nous n'ambitionnons pas de répondre dans le but de trancher un problème juridique qui a depuis longtemps reçu sa solution par d'autres voies et d'autres moyens. Nous voulons tout au plus tenter d'établir la valeur du jugement prononcé et montrer dans quelle mesure un tel document pouvait être fiable tant à son époque qu'à la nôtre. C'est pourquoi, au lieu d'adopter l'ordre qui lui était prescrit par les questions soumises à son opinion, nous préférons regrouper nos commentaires autour des différents points successivement touchés.

\section{Les problèmes}

\section{a - EXISTENCE LÉGALE ET DROIT DE PROPRIÉTÉ}

i. - Sous le régime français. - Dans son étude du "Contrat de donation du 9 mars 1663", Stuart, sauf pour la confusion qu'il fait entre le nom et le but de la donation, établit assez bien tous les titres légaux du Séminaire de Montréal. Il reconnaît que "letters patent bearing date in May, 1677, authorised the establishment of a Seminary at Montreal, for effectuating the 
object for which the Island had been thus given to the Seminary of St. Sulpice." (Par. 3)

Il réaffirme au paragraphe suivant que le roi de France a autorisé "to erect a Community and Seminary of Ecclesiastics on the Island of Montreal" (par. 4). Il mentionne explicitement la concession en mainmorte de la Seigneurie de Montréal, citant même le texte en français: "qu'elle soit unie, à perpétuité, à leur société, etc., pour en jouir par eux et leurs successeurs, etc." (par. 4).

Au cinquième paragraphe, il revient sur "a Community of Ecclesiastics there, which has been since known by the name of the Seminary of Montreal" (par. 5).

Pourtant, en répondant à la troisième question, Stuart, à l'encontre des lettres patentes de mai 1677 [et non 1667] insinue que le Séminaire de Montréal n'avait pas d'existence légale. Et il conclut : "On this ground, I am humbly of opinion that the Seminary of Montreal never had legal existence as a corporation distinct from the Seminary of St. Sulpice at Paris." (Par. 19) Déduction contradictoire avec la teneur du contrat de donation de 1663 et des lettres patentes de mai 1677, que Stuart connaît évidemment pour les avoir cités.

Il avait établi également que la communauté de Montréal était bien distincte de la communauté de Paris. "This community under the letters patent of May, $1677, \ldots$ continued, in its own name, to exercise acts of ownership in relation to the Island of Montreal, down to the period of the conquest by the British arms, in 1760" (par. 6). Et il poursuivait en contredisant ce qu'il venait d'affirmer, ignorant cette fois que le Séminaire de Montréal avait posé en son propre nom de fréquents gestes découlant de son existence légale et de son droit de propriété. Car il s'agissait bien d'une co-propriété.

L'existence légale, si bien établie par Stuart par recours aux textes, ne pouvait disparaître ensuite par des affirmations ou des négations gratuites.

ii. - Au moment de la conquête et après. - S'il est vrai que l'article 33 de la capitulation soumettait la survivance "au bon plaisir du roi", il n'est pas moins vrai de dire que l'existence légale n'était pas pour autant ni confirmée ni retirée. C'est peutêtre pourquoi les articles 34 et 35 accordaient et reconnaissaient le droit de propriété du Séminaire de Montréal découlant de cette existence. Réponse sans doute paradoxale si on la compare à la 
réponse à l'article 33 et qui pourrait probablement expliquer le silence total du procureur général à ce propos.

On serait porté à croire que Stuart enlevait ses lunettes pour lire les textes trop favorables au Séminaire de Montréal. Il a bien voulu ignorer entre autres que le bon plaisir du roi s'était exprimé dans les Instructions au gouverneur Carleton, reconnaissant l'autonomie des Sulpiciens de Montréal, comme groupe, comme corporation et non comme individus.

It is our Will and Pleasure... that the Society of Romish Priests, called the Seminaries of Quebec and Montreal, shall continue to possess and occupy their Houses and Lands, to which they were lawfully entitled on the 13th of September, 17594.

On comprend que l'existence légale et distincte du Séminaire de Montréal, la co-propriété, le droit de possession en mainmorte aient causé quelque embêtement à Stuart. Dans sa réponse à la première question (par. 14), il s'empresse de tout confondre ce qu'il avait si clairement établi au début de son exposé. A l'encontre des textes il affirmait que l'Ile de Montréal était la propriété unique des Sulpiciens de Paris. Son développement l'amenait sur un terrain glissant pour lui, le droit coutumier, la prescription et il terminait au plus tôt.

But independently of this source of right, the legal estate in the Seigniory of the Island of Montreal being vested in a foreign religious community incapable after the conquest of holding lands in a country subject to His Majesty's dominion, the right of property in it, from this cause alone, would necessarily devolve to His Majesty. (Par. 14)

Sans doute pourrait-on reconnaître que "being public property in the hands of that community as trustees for its administration and application, was acquired by His Majesty by right of conquest" (par. 14). Mais quelle différence y avait-il entre le droit de propriété en fidéicommission du Séminaire de Montréal et celui de n'importe quel seigneur ? Aucune. Sinon, autant dire que toute propriété privée tombait aux mains du roi d'Angleterre. Bien plus, à part l'article 34 de la capitulation, le roi d'Angleterre en avait décidé autrement que ne le voulait Stuart en exprimant son "Will and Pleasure" au gouverneur Carleton.

C'est pourquoi, non content de feindre l'ignorance, Stuart ira jusqu'à nier l'expression de la volonté royale, cinq paragraphes plus loin.

${ }^{4}$ W. P. M. Kennedy, Documents of the Canadian Constitution, 1759. 1915 (Toronto, 1918), 155: "Instructions to Governor Carleton, 1775", no 21, par. 11. 
I am not aware that, by any legal signification of the Royal pleasure, the Seminary of Montreal has since been re-integrated in a corporate character, if such it ever had (Par. 19).

Contre les documents très explicites du régime français comme du régime anglais, Stuart soulève donc plus qu'un doute sur l'existence légale de la corporation du Séminaire de Montréal. Et il insinue "it has since a distant period been merely a private association of individuals, who have without authority assumed to themselves a corporate name" (par. 19).

Le droit de propriété comme l'existence légale, étant déjà bien établis sous le régime français, nous paraissent encore plus incontestables par les documents de la conquête.

Sans doute l'Acte de Québec contenait-il sur ce point une exception pour les communautés religieuses.

Qu'il soit de plus décrété en vertu de l'autorité susdite, que tous les sujets canadiens de Sa Majesté dans la province de Québec, à l'exception seulement des ordres religieux et des communautés, pourront conserver la possession et jouir de leurs propriétés et de leurs biens avec les coutumes et usages qui s'y rattachent et de tous leurs autres droits civils, au même degré et de la même manière que si ladite proclamation et les commissions, ordonnances et autres actes et instruments n'avaient pas été faits, et que le permettront leur allégeance et leur soumission à la couronne et au parlement de la Grande-Bretagne.

Cependant, dans le cas particulier des Sulpiciens de Montréal, les garanties de l'article 34 de la capitulation retrouvaient toute leur valeur dans les Instructions royales au gouverneur Carleton.

Si les Sulpiciens de Paris et ceux de Montréal formaient des corporations légales distinctes, peut-on accepter que Stuart écrive à la fois "the grantors and grantees were members of one and the same corporation" (par. 16) et "incapable of conveying to another person"? On peut oublier sans trop d'inconvénient "vested with no rights of property".

\section{b - LE DROIT DE PROPRIÉTÉ ET LE BUT DE LA DONATION DE 1663}

Nous avons vu qu'en semant la confusion sur le but de la donation de 1663, Stuart faisait de ce but la condition sine qua non de la fondation du Séminaire de Montréal et donc de son existence légale (par. 12). Ce point rétabli plus haut à l'aide des textes, nous en retrouvons la substance dans le "Will and Pleasure" royal exprimé à Carleton dans ses Instructions de janvier 1775. "It shall be lawful for these Societies ... to educate 
Youth, in order to qualify them for the Service of Parochial Cures".

Si Stuart n'avait pas eu la mémoire si courte, il se serait rappelé ce texte et un autre également qu'il avait en toute probabilité déjà vu dans l'étude de Sewell au moment de sa cléricature ou dans le bureau du gouverneur Robert Shore Milnes quand il était son assistant-secrétaire. La lecture de "The St. Sulpician Estates, Revenue and Expenditure" 5 préparé par M. Roux, Supérieur du Séminaire, le 19 février 1800 en "réponse aux questions proposées", l'aurait dispensé de composer ses paragraphes 12, 23 et 24 .

Et une fois bien rétabli le but de la donation de 1663 et reconnu son parfait accomplissement, Stuart aurait admis en toute honnêteté que cette condition sine qua non fondait amplement l'existence légale et le droit de propriété du Séminaire de Montréal.

Il n'est pas exagéré de dire, croyons-nous, que rien n'est peut-être mieux préservé que le droit de propriété dans les textes de la conquête du Canada par l'Angleterre. Or ce droit, nous l'avons vu si exactement établi dans le cas de Saint-Sulpice de Montréal, sous le régime français comme sous le régime anglais, pourquoi Stuart ne le reconnaît-il pas puisqu'il mentionne les documents qui l'avaient fondé ? La gravité de ses omissions comme de ses affirmations à contresens ressort incontestablement dans leurs conséquences.

Avec facilité, il affirme qu'aucun document ne le fonde, alors que bien loin d'avoir été entamé au moment de la conquête, le droit de propriété des Sulpiciens de Montréal avait été confirmé. Une fois niée la propriété privée, quelle conséquence en découlait-il ?

\section{c - PROPRIÉTÉ PUBLIQUe?}

Il aurait été si facile au juriste Stuart de se dire que tout ce que la Couronne d'Angleterre n'avait pas explicitement changé dans un document légal avait conservé sa forme originale issue du régime français.

Il n'avait qu'à relire, pour s'en convaincre, ce passage de l'Acte de Québec.

5 Robert Christie, Interesting Public Documents and Official Correspondence illustrative of, and supplementary to the History of Lower Canada (Montréal, 1855), 6: 40-48. 
...qu'à l'égard de toute contestation relative à la propriété et aux droits civils, l'on aura recours aux lois du Canada, comme règle pour décider à leur sujet; et que toutes les causes concernant la propriété et les droits susdits, qui seront portées par la suite devant quelqu'une des cours de justice qui doivent être établies dans et pour ladite province, par Sa Majesté, ses héritiers et successeurs, y seront jugées conformément auxdites lois et coutumes du Canada, jusqu'à ce que celles ci soient changées ou modifiées par quelques ordonnances qui seront rendues de temps à autre dans ladite province, par le gouverneur, le lieutenant-gouverneur ou le commandant en chef en exercice, de l'avis et du consentement du Conseil législatif qui y sera établi de la manière ci-après mentionnée par les présentes.

Il soupçonnait d'ailleurs le principe du maintien des droits du régime français tant qu'un nouveau document n'était venu l'abolir ou le remplacer. Il l'utilisait en effet, mais en sens inverse chaque fois qu'il demandait un texte qu'il savait pourtant inexistant. Lui qui argumentait si souvent à partir du silence et de l'absence de documents (par. 7, 14, 15, 16, 19, 20), aurait-il été capable d'apporter un texte royal ou légal prouvant que la possession en fidéicommission avait été retirée à Saint-Sulpice ? Nous ne pourrions dire si, en sollicitant les textes, en tronquant certains écrits et en taisant ceux qui desservaient sa cause, Stuart imitait le "parti américain", comme on appelait les avocats loyalistes, mais les conclusions auxquelles il aboutissait étaient en tout identiques aux leurs. Voyons-le procéder.

By the 4th Article of the Treaty of Peace concluded between His Britannic Majesty and His Most Christian Majesty, on the 10th February, 1763, the latter ceded and guaranteed Canada and all its dependencies to His Majesty, in full right, with the Sovereignty, property, possession thereof, ... (Par. 8).

Principe très vrai sans aucun doute à partir duquel il tire une conclusion absolument fausse. "I conceive no doubt can be entertained that the Island of Montreal . . . was acquired by His Majesty by right of conquest ... under which His Majesty's right has been derived" (par. 14).

Ayant répondu dans le sens que nous venons de voir aux questions 1 et 3 , il aurait été dispensé de répondre aux questions 2 et 4 .

\section{d - L'ACTE DU 29 AVRIL 1764}

La possession en communauté de biens de la Seigneurie de Montréal par les Sulpiciens de Paris et ceux de Montréal ne subissait peut-être pas une grande modification sous l'effet de l'acte du 29 avril 1764. D'abord que manquait-il à ce document notarié pour avoir une valeur légale acceptable au procureur général ? Peut-être une insinuation au greffe judiciaire, comme 
l'insinuation au Conseil Souverain de 1677 que Stuart met pourtant en complet oubli ${ }^{6}$. Et après ? La consultation diplomatique qui l'avait précédé n'en tenait-il pas lieu, de même que la garantie de l'article 34 de la capitulation et la volonté royale du 7 janvier 1775 ?

Si ce raisonnement est bon, il faut donc déduire que tous les autres arguments de Stuart à propos de cet acte du 29 avril 1764 doivent tomber automatiquement: "the pretended deed of gift", "could not alienate", "vested with no right of property", "incapable of conveying to another person" (par. 15). A moins de vouloir prétendre que les lettres patentes de 1677 avaient fondé la corporation des Sulpiciens de Paris et non celle de Montréal, ce qui serait un non-sens, il faudra s'empresser de reconnaître avec Stuart que Louis XIV "authorised the establishment of a Seminary at Montreal ... His Majesty authorised the Seminary of St. Sulpice at Paris to erect a Community and Seminary of Ecclesiastics on the Island of Montreal" (par. 3). Comment alors pourrait-on inférer de là que "the grantors and grantees were members of one and the same corporation" (par. 16) ? Et tout le reste du paragraphe 16 tombe à la lecture des lettres patentes de mai 1677.

Faut-il encore rappeler que la fondation du Séminaire de Montréal, faite pour accomplir le but de la donation ne pouvait pas être remplie ailleurs qu'à Montréal. Et la donation était reconnue par le roi, non pas à un ensemble d'individus mais bien à une société, à une communauté, à un groupe "pour qu'elle soit unie, à perpétuité à leur Société, etc.... pour en jouir par eux et leurs successeurs" (par. 4), tel que cité en français par Stuart en son paragraphe 4 et extrait d'un document intitulé "Amortissement pour la Seigneurie de la dite Isle". Que reste-t-il alors du paragraphe 20 , surtout si on relit le paragraphe 16 lui-même appelé à disparaître ?

Une fois démontrée l'existence légale du Collège de Montréal, en corporation distincte de celui de Paris par lettres patentes du roi et l'attribution par la même circonstance des lettres d'amortissement, comment faudrait-il transformer la conclusion de Stuart?

6 "Dans l'espoir qu'ils vendraient leurs biens au gouvernement, on leur accordait 18 mois de délai. En cette extrémité, M. Etienne Montgolfier, alors supérieur du Séminaire, passa en France. Paris fit alors un geste magnifique qui sauva la situation. La maison-mère céda devant notaire tous ses biens du Canada au Séminaire de Montréal. M. Montgolfier rentra au pays avec les documents, qu'il fit enregistrer." Olivier Maurault, Nos Messieurs (Montréal, 1936), 28. 
If (as is not admitted but denied) the Seminary of Montreal had been a subsisting corporation, distinct from the Seminary of St. Sulpice, it could not have taken the estates in question without a license in mortmain. The French as well as the English law rendered "lettres d'amortissement," or a license in mortmain indispensably necessary for the validity of the deed of gift in question. Even if, in other particulars, it could have been deemed valid, the nullity of it, from the want of such authority, cannot be doubted (Par. 16).

Essayons de nous mettre d'accord avec Stuart et ses inspirateurs. Supposons que les Sulpiciens de Paris et ceux du Canada qui n'ont pas accepté de rester au pays après le 10 août 1764 , devenaient des étrangers et perdaient automatiquement droit de propriété. Comment alors peut-on interpréter les nombreux articles de la capitulation (art. $25,26,35,37,38,48$ ) qui permettaient aux administrateurs, aux militaires, aux compagnies d'affaire et aux particuliers, de vendre leurs biens et "d'emporter avec Eux, ou faire passer en France, le produit de quelque nature que ce soit, des biens vendus" ? Comment interpréter au surplus cette partie de l'article 4 du traité de Paris qui assure les mêmes garanties ? Ou bien c'était la confiscation générale au profit du roi à l'encontre des textes ou, en accord avec eux, le maintien des droits de propriété de tous.

\section{e - NATURALISATION}

Par le fait qu'ils avaient accepté de demeurer au Canada après le 10 août 1764 , comme le leur permettait le traité de Paris, les Sulpiciens de Montréal étaient devenus sujets du roi britannique par libre consentement ou si l'on préfère par droit de conquête. Mgr Maurault affirme que "28 Sulpiciens sur 40 acceptèrent de devenir sujets britanniques" " . En soutenant que les derniers survivants étaient morts vers 1795 ou 1796, Stuart oubliait que d'après le mémoire de M. Roux, M. Claude Poncin, arrivé au Canada avant la conquête, vivait encore le 19 février 1800. C'était se donner beaucoup de mal pour nier un droit de propriété que reconnaissait d'autre part la mainmorte. Londres, probablement très consciente de ce dernier fait, avait laissé s'établir au surplus un droit coutumier par sa tolérance qui s'était prolongée depuis 68 ans.

$\mathrm{La}$ "question de naturalisation" venait tout juste de se débattre de 1824 à 1827 entre le Haut-Canada et Londres ${ }^{8}$, autour du cas du député Barnabas Bidwell, né aux Etats-Unis avant 1783 , tout comme James Stuart lui-même. On y suggérait la reconnaissance comme sujet britannique avec tous les droits affé-

7 Olivier Maurault, Nos Messieurs, 28.

8 Rapport sur les Archives canadiennes (1898), Note C, 37-60. 
rants, soit par droit de naissance, soit après une résidence au pays depuis sept ans, soit encore par une autre procédure.

Quoi qu'il en soit, le procureur général du Bas-Canada semble ne vouloir rien entendre sur ce chapitre. C'est du moins ce que laisse croire le passage suivant : "and the Rev. Mr. Roux, in particular, who since that period has been and still is Superior of the Seminary, is a native of that country France, and has not been naturalized, though he has received within the colony Letters of Denization" (par. 11). Il n'y a vraiment rien à comprendre dans cette prise de position de James Stuart. Son raisonnement nous est exposé dans son paragraphe 22. Après avoir cité Pothier, un des meilleurs juristes français, il nous paraît conclure à contresens en affirmant : "He also states that this disqualification extended to the chief offices in seats of learning, and that aliens could not be principals or regents of a university. Letters of naturalization or "lettres de capacite" were indispensably necessary to remove this disability" (par. 22). Et pourtant, de sa propre affirmation, M. Roux avait reçu ses lettres de naturalisation. En réponse à toutes les subtilités, nous empruntons à Stuart un de ses passages :

These were not the property of the individuals composing the corporation, but that of the corporation itself, res universitatis, and were therefore incapable of alienation by one part of the members of the corporation to another part, nor were they susceptible of partition among them (Par. 16).

\section{$f$ - RECRUTEMENT}

En dépit de ses dénégations répétées, Stuart semble garder jusqu'à la fin le sentiment de n'avoir pas raison. Car après avoir prétendument établi l'inexistence d'un droit quelconque, il reprend ses attaques sous un nouvel aspect. Sans cesse, il nie ou il ignore les faits, oublie des documents essentiels ou en cite d'autres à contresens. On trouve un nouvel exemple de ces procédés dans le cas du recrutement qui pouvait se faire normalement, soit par des sujets étrangers au Canada, soit par des Canadiens de naissance.

Stuart pouvait-il ignorer que le roi avait exprimé sa volonté dans ses Instructions à Carleton sans exclure aucune forme de recrutement?

It is our Will and Pleasure that ... it shall be lawful for those Societies to fill up vacancies and admit new Members according to the Rules of their Foundation...

Voilà une phrase qui révèle chez le roi une meilleure information que chez Stuart, comme il ressort de son paragraphe 21 . 
In this respect the Seminary of Montreal, and also the Recollets and Jesuits were disadvantageously distinguished from the other religious communities in the Province inasmuch as the latter, according to the rules of their foundation, could obtain a renewal of their members by a domestic supply, whereas the former could only receive it from the alien parent establishments in Europe, to which they belonged, and this source was closed by the conquest (Par. 21).

Quant aux Sulpiciens, ou bien ils connaissaient mieux que Stuart la volonté royale exprimée en 1775 ou bien ils ignoraient l'esprit des constitutions de leur Institut. De toute façon ils étaient en désaccord avec l'opinion de Stuart, puisque, d'après le rapport du 19 février $1800,27.2 \%$ de leur personnel était canadien, soit 6 sur 22. Fait qu'il traite à la légère en disant vaguement: "The gentlemen composing this body, since the period last mentioned, with few exceptions, have been natives of France, not naturalized." (Par. 11)

Les quinze autres Sulpiciens de la liste de 1800 étaient venus avec l'autorisation expresse, l'approbation tacite du gouverneur. Mais Stuart leur refuse même le droit d'appartenir à Saint-Sulpice de Montréal. "Personne subsequently admitted to be members of the latter Seminary Paris, could, therefore, have no claim, on that ground, to be members of the former Montreal. ... According to the law of France and the law of this Province at it now stands, aliens and even denizens are incapable of being members of a corporation." (Par. 21)

\section{$\mathrm{g}$ - Quelques AUTRES QUESTIONS}

Avant de terminer cette partie de notre étude, il nous resterait trois questions à traiter : la mainmorte, le droit coutumier, et l'importance de l'incorporation civile.

Pour la mainmorte, nous nous contenterons, à titre de renseignement, de citer le dictionnaire :

Droit. Gens de mainmorte : corps, communauté, association dont l'existence est perpétuelle, à raison du renouvellement constant de leurs membres et dont les biens sont par suite soustraits aux mutations par décès. Biens de mainmorte : biens appartenant à des personnes morales (communes, départements, hospices, congrégations religieuses, sociétés anonymes, sociétés savantes) et qui ne changent pas de main comme le font, au moins par décès de ces derniers, les biens des personnes physiques ${ }^{9}$.

Le droit coutumier relatif aux biens de Saint-Sulpice de Montréal peut s'exprimer brièvement en chiffres. Cent cinquanteet-un ans s'étaient écoulés depuis les lettres patentes de 1677 et

${ }^{9}$ Grand Larousse encyclopédique $d u X X^{e}$ siècle, S. V. mainmorte. 
soixante-huit depuis la conquête. Depuis ce temps Londres avait constamment rejeté ou laissé tomber toutes les réclamations contre ces biens.

Pour ce qui est de l'importance de l'incorporation civile, elle est incontestable, car sans elle aucune activité légale, économique ou judiciaire n'est possible et c'est la mort à brève échéance des organismes qui en sont privés. Ajoutons que l'incorporation civile de Saint-Sulpice de Montréal était de beaucoup mieux établie que ne l'était celle de n'importe quelle autre institution religieuse en général et que celle de l'Eglise catholique elle-même en particulier. Pour nous en convaincre, il suffira d'évoquer trois faits. Les deux premiers ont marqué des étapes vers le règlement final et définitif qui constitue le dernier fait.

L'antithèse entre le droit et le fait ecclésiastique catholique romain avait commencé à exister dès le jour où $\mathrm{Mgr}$ Briand était revenu au Canada en 1766, consacré évêque avec l'agrément officieux du gouvernement britannique, mais sans avoir obtenu la reconnaissance légale de son titre et de sa fonction. Depuis lors, grâce à une sorte d'entente tacite et à une bonne volonté mutuelle, un modus vivendi satisfaisant s'était établi et avait persisté. Mais après plus d'un quart de siècle un fait nouveau était venu mettre fâcheusement en lumière cette situation indécise. En 1793, le gouvernement de la métropole avait nommé un évêque anglican à Québec. Et au bout de quelque temps cet évêque de Québec, s'apercevant qu'il $\mathrm{y}$ avait ici un autre dignitaire à qui l'on décernait le même titre, prit ombrage de cet état de choses et s'en plaignit. Dès son arrivée au Canada il avait appelé l'attention du ministre sur la position respective de l'église catholique romaine et de l'église anglicane. Ce sujet revint souvent sous sa plume ${ }^{10}$.

Nous y retrouvons un modus vivendi, un accord tacite, une tolérance réciproque, enfin un droit coutumier dont on connaît la force et l'importance et où le droit anglais se distingue particulièrement.

Le deuxième est plutôt une série de faits étudiés par J.-P. Wallot dans "Sewell et son projet d'asservir le clergé canadien (1801)", RHAF, 16 (mars 1963) : 549-566.

Le troisième fait est raconté par Antonio Perrault dans son intéressante étude sur l'histoire du Conseil spécial et de sa législation. Il écrit:

Le 19 mars 1839, adoption d'une ordonnance concernant les immeubles possédés par les paroisses, missions, congrégations ou sociétés

10 Lettres de l'évêque Mountain à Dundas, à Portland, à sir Robert Shore Milnes et à lord Camden, 20 novembre 1793, 15 avril 1799, 6 juin 1803, 24 octobre 1804; Archives du Canada : Papiers d'Etat du BasCanada, Q., 69-2, p. 83, 92, 96. Tiré de Thomas Chapais, Cours d'Histoire dw Canada (8 vol., Québec, 1919-1931), 2 : 132. 
de chrétiens, de quelque dénomination que ce soit (2 Vict., ch. 26). Modifiant une loi remontant à l'année 1830 (10 et $11 \mathrm{Geo} .4$, ch. 58), celle du 19 mars 1839 reconnaissait le titre de ces paroisses, congrégations chrétiennes aux terrains qu'elles possédaient et elle leur permettait d'en acquérir d'autres; les constituant en corporation, elle leur accordait le droit d'ester en justice ${ }^{11}$.

Edmond Lareau, dans son Histoire du droit canadien, écrivait en 1889 que cette ordonnance "mettait toutes les religions chrétiennes en dehors du contrôle du gouvernement et assurait leur liberté d'action" ${ }^{12}$.

Il faut toutefois être conscient du danger qu'il y aurait de nous en tenir trop strictement à la teneur de ce texte en le détachant des documents antérieurs qui ont marqué sur ce point l'évolution de toute une pensée. Pour juger de l'importance et de l'étendue du débat dont furent l'objet Saint-Sulpice et ses biens, on n'a qu'à considérer la masse documentaire accumulée durant plus d'un demi-siècle. Mais on ne peut certes pas se dispenser de jeter un rapide coup d'œil sur la personnalité et la carrière de l'auteur qui a produit l' "opinion légale" du 10 décembre 1828.

\section{III. - L'homme}

James Stuart était né aux Etats-Unis quarante-huit ans plus tôt, à la fin de la Révolution américaine. A cause de ses attaches à la Couronne britannique, sa famille avait dû, comme bien d'autres, émigrer au Canada. James alla faire ses études à Kingston puis en Nouvelle-Ecosse, contrées loyalistes, où il eut pour compagnon Robert Christie, futur député au Bas-Canada et auteur de History of Lower Canada. L'ascension sociale et professionnelle de Stuart commença même avant son admission à la pratique du droit, qui devait coïncider avec ses vingt-cinq ans. Sa carrière se partagea ensuite entre l'activité du juriste et celle de l'homme politique passant alternativement de l'une à l'autre.

\section{A. - LE JURISTE}

$\mathrm{Au}$ temps de sa cléricature chez le célèbre Jonathan Sewell, alors illustre par ses préjugés anticatholiques et anticanadiens au sein du célèbre trio Mountain-Ryland-Sewell, Stuart était devenu l'assistant-secrétaire du gouverneur Robert Shore Milnes. A peine reçu au Barreau, en 1805, il était nommé solliciteur général du Bas-Canada par le gouverneur dont il partageait les

11 Antonio Perrault, "Le Conseil spécial, 1838-1841", Revwe du Barreau de la Province de Québec, 3 (1943) : 268.

12 E. Lareau, Histoire du droit canadien depuis les origines de la colonie jusqu’à nos jours (2 vol., Montréal, 1889), 2 :446-452. 
vues politiques ${ }^{13}$. Le jeune homme était ambitieux de continuer à brûler les étapes. En 1808, la promotion de Bowen au poste de procureur général fit éclater chez Stuart une amère déception qui l'amena à des attaques publiques contre le nouveau titulaire. Le gouverneur Craig ne l'entendit pas de la même oreille et il destitua immédiatement Stuart de son poste.

Cette déposition devait retarder de vingt ans l'accomplissement de son désir. En 1825, le gouverneur Dalhousie le nomma enfin procureur général, récompense politique "pour être revenu au parti ministériel", c'est-à-dire au Family Compact, affirme P.-G. Roy ${ }^{14}$.

A ce poste, il fit preuve de tant de partialité, d'avidité et d'arrogance qu'il souleva contre lui la magistrature, les électeurs et les hommes politiques. A la fin de 1828, commença une enquête sur l'administration de la justice qui se prolongea durant deux ans et produisit trois longs rapports qui furent déposés devant la Chambre d'Assemblée. La destitution de Stuart réclamée par le public et par les députés fut enfin accordée en 1831 par Aylmer. D.-B. Viger fut même délégué en Angleterre pour "soutenir les accusations que portaient les Canadiens contre le procureur général" ${ }^{15}$.

13 Pour saisir le sens précis de cette expression, on lira J.-P. Wallot, "Sewell et son projet d'assertissement du clergé (1801)", dans RHAF, 16 (mars 1963) : 549-566. On y trouvera en note (p. 552) le résumé de deux carrières qui ont pu inspirer celle de Stuart.

Sewell, le chef le plus prestigieux du parti anglais, était né aux Etats-Unis, à Cambridge, Mass., en 1766. Après des études en Angleterre, il se transplanta à nouveau, cette fois au Nouveau-Brunswick, où il aborda l'étude du droit sous Ward Chipman. Reçu avocat du Bas-Canada, en 1789, il fut pistonné aux postes d'avocat général et d'inspecteur général du domaine royal, en 1793, puis de procureur et d'avocat général, en 1795. Il siégea à l'Assemblée, de 1796 à 1808 , comme représentant du Bourg William Henry. En mai 1808, il était promu juge en chef de la province, L'Assemblée connaissait ses idées. Elle le mit en accusation, en 1814, de même que Monk, sur leur conduite judiciaire. Le Conseil privé débouta ces accusations. Et Sewell allait continuer à jouer un rôle prédominant dans la politique canadienne, jusqu'à sa mort, le 12 novembre 1839. En 1810 et en 1824, il militera activement pour l'union des Canadas.

[Foucher], solliciteur général (depuis 1795), un Canadien jugé "transfuge" par le parti patriote, devint juge provincial pour le district des Trois-Rivières, en 1802, et juge puîné, à la Cour du banc du roi de Montréal, en 1812. En 1817, la Chambre allait l'inculper d'incompétence et de partialité dans l'exercice de ses hautes fonctions. Elle finit par laisser tomber ces accusations.

14 Les Juges de la province de Qwébec, 515.

15 E.-Z. Massicotte, dans les Cahiers des dix, 10 (1945) : 250. 
En voilà déjà suffisamment pour comprendre que les nominations de Stuart étaient publiquement connues ainsi que ses destitutions comme des décisions politiques, des récompenses ou des désaveux ${ }^{16}$.

Stuart mourut en 1853. Quatre ans plus tard, un contemporain qui l'avait bien connu, Maximilien Bibaud jugeait le juriste en ces termes :

Sir James Stuart a joui d'une réputation colossale, mais sujette à contestation. S'il n'avait été qu'avocat, on ne saurait nier qu'il ne fut comme tel fort brillant par son éloquence et son érudition; mais comme officier de la Couronne et comme Grand Juge, il a prêté flanc à la critique, non moins que comme homme politique ${ }^{17}$.

\section{B. - L'HOMME POLITIQUE}

Eh, oui ! Stuart fut un politicien et, à ce titre, il fut encore plus discutable par ses préjugés et ses alternances entre le parti du gouverneur et le parti canadien. Sa carrière politique commença dès 1808 , lors de sa déposition par Craig. Cessant d'être solliciteur général, il décida de se faire élire député. C'était plus qu'un simple passage d'une fonction à une autre, vu qu'il exerçait une revanche contre l'adversaire vainqueur en devenant l'allié et même l'un des chefs du parti canadien. Il n'y connut d'ailleurs pas plus de stabilité, car il se fit bientôt l'ardent défenseur du projet d'Union de $1822^{18}$.

Un peu suivant le style de l'époque, les campagnes politiques de Stuart ont toutes été marquées de turbulence et ont laissé des traces parfois sanglantes, voire même mortelles ${ }^{19}$.

En 1827, le procureur général et conseiller exécutif James Stuart voulut devenir au surplus député à la Chambre pour le bourg de William Henry (Sorel). Malgré l'appui à peine voilé du gouverneur Dalhousie qui était un de ses électeurs, en dépit de son propre chantage dans le bureau de votation, de ses menaces, de ses contraintes au parjure ou faux serment, le candidat fut défait aux mains du Dr Wolfred Nelson. Le procureur général

16 On pourra juger du comportement de l'homme de loi dans la captivante étude du Maréchal Nantel, "Autour d'une décision judiciaire sur la langue française en Canada" (1812), dans les Cahiers des dix, 6 (1941) : 147-165.

17 Dictionnaire historique des hommes illustres, 307.

18 Cette campagne épique a été racontée par Léo-Paul Desrosiers, "Montréal soulève la Province", dans les Cahiers des dix, 8 (1943) : 75-107.

19 Pour l'élection de 1808, voir les Cahiers des dix, 7 (1942): 251; celle de 1811, les Cahiers des dix, 8 (1943): 178. 
exerça ensuite ses vengeances contre ses adversaires politiques et son comportement entraîna en bonne partie l'enquête sur l'administration de la justice qui aboutit à sa destitution en 1831.

Stuart n'était pas l'homme à se laisser abattre facilement. Sa campagne électorale de 1834 fut marquée d'un meurtre ${ }^{20}$.

\section{C. - AUTRES PROMOTIONS}

Même si la Chambre d'Assemblée avait demandé et obtenu la destitution de Stuart en 1831, sa radiation définitive pour tout poste public également réclamée ne fut pourtant que temporaire. Stuart devint juge en chef du district de Montréal; il fut choisi par Colborne comme membre du Conseil spécial et élevé plus tard au rang de président. Et sa dernière victoire, cette fois comme juge en chef du Bas-Canada, fut sans doute de compter parmi les principaux rédacteurs de l'Acte d'Union. "He had much to do with the framing of the Act of Union, $1840 " 21$.

Au poste de juge en chef il avait remplacé Sewell, son ancien concurrent.

\section{D. - JUGEMENTS DE SES CONTEMPORAINS}

Ce sont probablement tous ces faits qui, en 1857, ont fait écrire à Bibaud que Stuart était "une girouette politique". Devant un tableau si chargé, on serait porté à croire que toutefois le personnage devait jouir d'une certaine grâce doublée d'une adroite diplomatie qui lui faisait pardonner ses excès et gagner du même coup la faveur tantôt des uns, tantôt des autres, au gré de son opportunisme. Pourtant au témoignage de ses victimes qui sont devenues les témoins au cours de l'enquête sur l'administration de la justice, Stuart était un vindicatif, un avide, un ambitieux, un revanchard. La "Pétition des Habitants de Montréal" demandait la tenue d'une enquête sur

cet homme enhardi par l'impunité, et se flattant, à ce qu'ils pensent, qu'aucune puissance ne saurait l'arrêter dans la course de l'injustice et de l'iniquité, [qui] a osé, au préjudice des intérêts de cette province, faire un instrument de spéculation pécuniaire, de la situation que Sa Majesté lui a confiée, en bonne foi, pour le bien public.

Pagnuelo a laissé des notes intéressantes au sujet de Stuart. Démis de sa fonction de solliciteur général en 1808, écrit-il,

20 Cahiers des dix, 20 (1955) : 228.

21 Wallace, Dictionary of Canadian Biography. 
M. Stuart se lança alors dans le parti de l'opposition ou des Canadiens, dont il fut l'un des chefs les plus ardents pendant plusieurs années et jusqu'à ce que les accusations qu'il avait portées contre le juge Sewell à qui il avait juré une haine implacable, eussent été finalement abandonnées par l'Assemblée. De dépit, il se tourna contre les Canadiens, dont il fut l'ennemi, et marcha de nouveau avec le gouvernement; il travailla pour l'Union des Canadas, en 1822, chercha à persécuter les Canadiens et les Catholiques ${ }^{22}$.

\section{E. - Les CIRCONSTANCES DE LA RÉDACTION}

La critique externe de ce document ne serait certes pas complète si nous omettions de jeter au moins un rapide coup d'œil sur les circonstances qui en ont précédé ou accompagné la rédaction. Elles apporteront des informations supplémentaires. L'examen soigneux de cette fameuse pièce nous a permis de déceler les principales erreurs et de les rectifier. L'exposé de la double carrière de son auteur, partagé sans cesse entre la magistrature et la politique, nous a montré son caractère ambitieux, opportuniste, exploiteur et tortueux. Le climat psychologique de ce document nous a été fourni en bonne partie par les principales sources de son inspiration jurisprudentielle. Nous pourrons maintenant retracer l'atmosphère sociale et professionnelle qui a entouré l'étude de la question sulpicienne et la formulation du jugement du procureur général, en rappelant quelques événements majeurs qui ont marqué cette période.

Le 10 décembre 1828, Stuart signait le document qu'on lui avait demandé six mois plus tôt. Il restait alors moins de vingt jours avant que la Chambre d'Assemblée ne réclamât la formation d'un comité d'enquête sur l'administration de la justice. Or, non seulement le procureur général était le grand responsable de celle-ci, mais il devait être le seul personnage mis en cause. Et voici pourquoi. Depuis sa défaite politique de William Henry, en juillet 1827, James Stuart, profitant de sa haute fonction, n'avait cessé d'exercer ses revanches contre les électeurs de son adversaire, le Dr Wolfred Nelson. Conformément aux menaces qu'il avait faites durant sa campagne électorale, il avait traîné en justice, au cours des deux années écoulées, une trentaine de personnes dont il avait privé quelques-unes de leur droit de vote parce qu'elles avaient refusé de se parjurer. Au dire des témoins, il avait tenté de les ruiner par des délais injustifiables. Après les avoir obligées à de coûteux déplacements et à d'interminables séjours loin de leurs demeures, il les avait finalement remises au prochain terme des cours de

$22 \mathrm{~S}$. Pagnuelo, Etudes historiques et légales sur la liberté religieuse en Canada, 84, note 1 . 
justice. En effet, les juges ne siégeaient dans les districts judiciaires qu'à tous les trois ou quatre mois. A la fois juge et partie dans ces différentes causes, Stuart avait passé outre aux juridictions des tribunaux et s'était arrogé des pouvoirs qui n'étaient nullement les siens. En conséquence, on l'imagine facilement, le climat général de la province était passablement chargé. L'orage qui s'était amoncelé depuis ce temps allait bientôt éclater.

Bien plus, à l'intérieur même de sa profession, le procureur général avait créé une indisposition générale qui s'était ajoutée à la précédente. Là aussi, il avait outrepassé ses droits et ses devoirs. Mais il avait affaire à des avocats et à des notaires qu'il avait voulu contraindre à renouveler leurs commissions d'homme de lois sous de fallacieux prétextes. Ils eurent d'autant plus facilement gain de cause contre lui qu'en modifiant de son propre chef la loi, pour mieux les forcer, il avait tenté de restreindre leur liberté et leurs pouvoirs. Il n'en fallait pas davantage pour provoquer la nausée générale sur l'administration de la justice.

Il serait bien étonnant que ce projet d'enquête sur la justice fût demeuré secret jusqu'à sa révélation en Chambre d'Assemblée le 29 décembre 1829. Et Stuart, conscient de la menace qui pesait sur lui, put voir dans la demande du gouverneur et du Conseil exécutif l'occasion toute souhaitée de redorer son blason. Il se souciait assez peu d'en faire payer le prix par les Sulpiciens. A propos de ce fameux document, Pagnuelo a écrit :

C'était un ballon d'essai lancé par le Gouverneur pour sonder l'opinion publique. Lord Dalhousie remit la question devant le Conseil Exécutif le 6 mai 1828, et le 17 juin, son secrétaire, M. Cochrane, demanda à James Stuart, alors procureur général, converti depuis peu au gouvernement, non par principe, mais par dépit, après lui avoir fait la guerre tant d'années par dépit, lui demanda, dis-je, son opinion légale, sur la validité du titre du Séminaire, sur son existence légale comme corps, sur le droit de la Couronne aux biens qu'il possédait et les moyens de s'en mettre en possession. 23

Parler d'un "ballon d'essai", n'était-ce pas recourir à un euphémisme? Car les seules questions, on l'a vu, orientaient déjà les réponses et indiquaient dans quel sens on les voulait. D'autre part, Stuart, bien connu pour son avidité d'honneurs, d'argent et de profitable popularité, était également bien connu pour son arrivisme, toujours prêt à sacrifier même ses meilleurs amis pour obtenir un gain désiré. S'il ne nous avait lui-même fourni de nombreux exemples d'achat de promotions par des volte-face et des trahisons, nous pourrions craindre de soup-

23 Pagnuelo, ouvrage cité, 83. 
çonner ses intentions et sa droiture. Pour nous consoler, disons qu'il avait les défauts de ses qualités.

Incontestablement érudit en droit anglais comme en droit français, James Stuart manquait toutefois de logique et de méthode, qualités pourtant indispensables à un juriste. Informé certes en droit civil français, quelle véritable formation possédait-il ? Ses contemporains l'ont constaté par les jugements erronés les plus célèbres qui lui furent imputés : "son ordonnance des bureaux d'hypothèques, son opinion non motivée sur l'amovibilité des cures, et sa décision sur les titres des Sulpiciens" ${ }^{24}$. Sans compter évidemment les interprétations à rebours de certains textes qu'il cite. Et ce que l'on affirme du droit civil peut également se dire du droit ecclésiastique.

On comprend mieux maintenant pourquoi Maximilien Bibaud n'a pas cru dépasser la mesure dans son jugement de 1857. "Ses contemporains et M. Christie, son ami de collège, ont donc exagéré son mérite ... [Stuart] n'avait pas de principe; violent au point d'être factieux, comme député, il a manqué de calme et de dignité comme magistrat." Pourtant cette conclusion a été supprimée dans l'édition de 1891 par les nièces de Bibaud qui en ont fait la préparation.

\section{IV. - CONCLUSION}

N'est-il pas généralement reconnu que la vérité doit toujours l'emporter sur le triomphe d'une cause ou d'une autre qui ne lui serait pas conforme ? C'est même un postulat de l'esprit d'où il découle que si l'histoire ou la recherche historique est souvent en pareil cas l'auxiliaire principal des hommes de loi ou vice versa, la poursuite de la vérité doit demeurer l'objectif commun des juristes comme des historiens. Dans la présente question, on peut se demander, on doit même chercher à savoir si les juristes anglais engagés dans cette affaire des Sulpiciens ont eu ou non de semblables ambitions. N'interprétaient-ils pas le droit civil français toujours en vigueur au Canada ?

Apprécier à sa juste valeur l' "opinion légale" de Stuart n'est certes pas chose facile, on le devine. Car les points de droit impliqués dans la cause sulpicienne, peut-être plus encore que dans tout le reste de la question seigneuriale, s'enchaînaient de telle façon qu'ils devaient être examinés et réglés à l'intérieur d'un même système de lois. Or le régime seigneurial avait été lon307.

24 Maximilien Bibaud, Dictionnaire historique des hommes illustres, 
guement élaboré et avait fonctionné au sein du système légal et juridique de la France et selon la coutume de Paris qui en était la règle.

Pour le moment, disons que les juristes anglais nous semblent avoir eu beaucoup plus tendance à se faire législateurs que simples interprètes de lois existantes. Remarquons toutefois que, jusqu'à un certain point, c'était peut-être le rôle demandé à Hey, Mazères, Marriott et aux juristes de 1789, de proposer de nouvelles formes de loi pour régir en particulier le système seigneurial. Mais Stuart, pas plus que l'avocat de la cause Fleming ${ }^{25}$, ne pouvait considérer de telles propositions comme une jurisprudence authentique tant qu'elles n'avaient pas revêtu la forme d'une loi à la législature du Bas-Canada et reçu la sanction royale. En faisant une jurisprudence de ce qui n'était même pas une opinion légale, mais de simples propositions, les avocats anglais du Canada, y compris le procureur général Stuart, oubliaient que le gouvernement londonien n'avait jamais appliqué les recommandations de ces rapports.

Posons-nous alors quelques questions avant d'esquisser un jugement.

$1^{\circ}$ Le droit civil français n'était-il pas encore en vigueur, et même, au dire de certains constitutionnalistes de Londres, n'avait-il pas été maintenu sans interruption depuis la conquête, en dépit de la Proclamation royale et de l'ordonnance du 17 septembre 1764 pour créer les cours de justice ? Murray ne l'avait-il pas appris à ses dépens ?

$2^{\circ}$ Les avocats et juristes anglais du Canada devaient-ils ou même pouvaient-ils interpréter ce droit civil français selon le droit public anglais ? Si oui, le maintien du droit civil français avait-il encore quelque signification ? Il est incontestable que le droit public anglais en vigueur comme conséquence automatique de la conquête, mais avec cette clause restrictive inclue dans l'Acte de Québec que le droit civil français devait être respecté intégralement jusqu'à ce que la législature provinciale l'ait formellement modifié et adapté. Or il est incontestable que Stuart a suivi, comme une véritable jurisprudence, les opinions et les suggestions de Marriott et des juristes de 1789 comme avait pu le lui enseigner son patron Sewell et ses amis Ryland

${ }^{25}$ La cause Fleming était la dernière en date qui avait opposé seigneurs et censitaires de Montréal. Jugée en 1816, elle fut déboutée en première instance et la Cour d'appel confirma par la suite le premier jugement. 
et Ellice. Telle était l'œuvre principale de ceux que Chapais appelle le "parti américain".

$3^{\circ}$ Cette pseudo jurisprudence toute anglophile triomphait contre tout droit à l'époque de Stuart tout en soulevant une vague contestation. Et ce ne fut pas avant la deuxième moitié du $\mathrm{XIX}^{\mathrm{e}}$ siècle, donc une fois abolie la tenure seigneuriale, que les juristes canadiens acquirent assez de valeur pour apporter une base légale ${ }^{26}$ à la contestation désormais inutile.

$4^{\circ}$ Si l'exercice du sens critique sur le document de Stuart est aujourd'hui difficile, n'est-il pas moins nécessaire et plus possible qu'il ne l'était en 1828, précisément à cause des travaux de nos juristes canadiens et de la publication de nombreux documents alors ignorés ou secrets?

En conséquence, l'historien comme le juriste du $\mathrm{XX}^{\mathrm{e}}$ siècle, qui veut étudier la tenure seigneuriale sous le régime anglais ou même la question sulpicienne, ne peut certes pas accepter sans un examen minutieux l' "opinion légale" de Stuart.

$5^{\circ}$ Nous irions plus loin en demandant si cette prétendue jurisprudence anglophile du Canada s'était bien conformée à l'esprit du droit anglais ou si elle ne cherchait pas tout simplement à couvrir des apparences de la légalité un ambitieux "partage des dépouilles"? S'il faut répondre non à la première hypothèse, la seconde se trouve bien fondée dans le cas de Sewell, Ryland et Ellice qui ont vécu dans le voisinage de Stuart.

Jusqu'ici le document du procureur général de 1828 nous a donné le spectacle d'un honteux découpage de textes et d'une érudition juridique mal organisée qui ne pouvaient assurément pas préparer le triomphe de la vérité. Si Stuart était excusable de ne pas connaître l'opinion royale obtenue par voie diplomatique à propos du document du 29 avril 1764, son ignorance des Instructions à Carleton et son oubli de l'Acte de Québec l'étaient beaucoup moins. Manquait-il vraiment d'information et ses erreurs étaient-elles dues à une méthode insuffisamment rigoureuse?

Quoi qu'il en soit, il n'a pas manifesté les connaissances nécessaires pour fonder solidement son jugement. De plus son manque de sens critique et d'objectivité lui a fait adopter une

${ }^{26}$ B.-A. Testard de Montigny, Histoire du droit canadien (Montréal, 1869). - S. Pagnuelo, Etudes historiques et légales sur la liberté religieuse en Canada (Montréal, 1872). - Edmond Lareau, Histoire du droit canadien, (2 vol., Montréal, 1888-1889). 
jurisprudence des opinions légales surtout ambitieuses de confisquer des biens pourtant reconnus par la capitulation, le traité de Paris et les Instructions à Carleton.

Il ne faudrait pas terminer cette étude sans signaler le jugement peut-être le plus décisif sur l'opinion de Stuart, parce que d'un seul coup il en a annulé tous les effets. Ce jugement fut prononcé par Stuart lui-même, au moment où, déposant son document, il a mentionné au gouverneur le droit coutumier qu'il avait si soigneusement laissé dormir aux oubliettes. La confiscation soudaine de cette propriété, soixante-dix ans après la conquête, aurait soulevé la population catholique et provoqué la Chambre d'Assemblée déjà suffisamment tumultueuse.

Enfin, quand le 6 juin 1840, le Conseil spécial étudiait le problème sulpicien, le juge en chef Stuart, son président, s'abstint de voter sous le motif suivant :

The Honorable, Chief Justice stated, that he must beg leave to decline voting on this proposed ordinance as having given an official opinion as Attorney General of the Province, on the subject involved in it, and as having subsequently been counsel for the Seminary, and by them consulted in relation to this matter, after he had ceased to held office under the Government 27.

GEORGES-Émile GIGUÈRE, s.j.

${ }_{27}$ A. Perrault, article cité, 227. 